\title{
Effect of blood loss during caesarean section on coagulation parameters
}

Citation for published version (APA):

Wasserloos, A., Thomassen, M. C. L. G. D., Costa, S. D., Zenclussen, A., Tchaikovski, V. E., Hackeng, T. M., Stickeler, E., \& Tchaikovski, S. N. (2021). Effect of blood loss during caesarean section on coagulation parameters. Thrombosis Research, 202, 84-89. https://doi.org/10.1016/j.thromres.2021.03.010

Document status and date:

Published: 01/06/2021

DOI:

10.1016/j.thromres.2021.03.010

Document Version:

Publisher's PDF, also known as Version of record

Document license:

Taverne

Please check the document version of this publication:

- A submitted manuscript is the version of the article upon submission and before peer-review. There can be important differences between the submitted version and the official published version of record.

People interested in the research are advised to contact the author for the final version of the publication, or visit the DOI to the publisher's website.

- The final author version and the galley proof are versions of the publication after peer review.

- The final published version features the final layout of the paper including the volume, issue and page numbers.

Link to publication

\footnotetext{
General rights rights.

- You may freely distribute the URL identifying the publication in the public portal. please follow below link for the End User Agreement:

www.umlib.nl/taverne-license

Take down policy

If you believe that this document breaches copyright please contact us at:

repository@maastrichtuniversity.nl

providing details and we will investigate your claim.
}

Copyright and moral rights for the publications made accessible in the public portal are retained by the authors and/or other copyright owners and it is a condition of accessing publications that users recognise and abide by the legal requirements associated with these

- Users may download and print one copy of any publication from the public portal for the purpose of private study or research.

- You may not further distribute the material or use it for any profit-making activity or commercial gain

If the publication is distributed under the terms of Article $25 \mathrm{fa}$ of the Dutch Copyright Act, indicated by the "Taverne" license above, 


\title{
Full Length Article
}

\section{Effect of blood loss during caesarean section on coagulation parameters}

\author{
A. Wasserloos ${ }^{a}$, M.C.L.G.D. Thomassen ${ }^{b}$, S.D. Costa $^{c}$, A. Zenclussen ${ }^{\mathrm{d}}$, V. Tchaikovski ${ }^{\mathrm{e}}, \mathrm{T}$. \\ M. Hackeng ${ }^{\text {b }}$, E. Stickeler ${ }^{\text {a }}$, S.N. Tchaikovski ${ }^{\text {a, * }}$ \\ ${ }^{a}$ University Clinic for Gynaecology and Obstetrics, RWTH Aachen, Germany \\ ${ }^{\mathrm{b}}$ Department of Biochemistry, Cardiovascular Research Institute Maastricht, Maastricht University, the Netherlands \\ ${ }^{\mathrm{c}}$ Women's Hospital, Otto-von-Guericke University, Magdeburg, Germany \\ d Experimental Obstetrics and Gynecology, Medical Faculty, Otto-von-Guericke University, Magdeburg, Germany \\ e Academic Teaching Hospital of RWTH Aachen University, Rhein-Maas Clinic, Germany
}

\section{A R T I C L E I N F O}

\section{Keywords:}

Blood loss

Coagulation

Caesarean section

\begin{abstract}
A B S T R A C T
Introduction: Venous thrombosis is the leading cause of pregnancy-related maternal morbidity and mortality. The thrombosis risk is increased by caesarean section and blood loss, though underlying mechanisms of these prothrombotic changes remain unknown.

Materials and methods: This prospective study recruited 50 pregnant women at term undergoing elective caesarean section at University Hospital Magdeburg, Germany. Blood loss during surgery was correlated with the changes in total protein $\mathrm{S}$, full length TFPI $\left(\mathrm{TFPI}_{\mathrm{fl}}\right)$, prothrombin, the endogenous thrombin potential (ETP) and resistance to activated protein C (APCsr) determined via calibrated automated thrombography.

Results: Mean blood loss was $506 \mathrm{ml}$ (95\%CI: 456 to $557 \mathrm{ml}$ ). Total protein S was 0.63 (95\%CI: 0.60 to 0.67 ) U/ $\mathrm{ml}$ preoperatively, decreased by $14.8 \%$ after caesarean section and almost normalised five days later. $\mathrm{TFPI}_{\mathrm{fl}} \mathrm{Was}_{\mathrm{f}}$ 0.47 (95\%CI: 0.41 to 0.53 ) $\mathrm{U} / \mathrm{ml}$ before, remained unchanged immediately after and increased by $11.5 \%$ five days after surgery. Prothormbin was 1.10 (95\%CI: 1.03 to 1.16 ) U/ml preoperatively, reduced by $10.4 \%$ immediately after and increased again five days after caesarean section, exceeding the preoperative values by $4.4 \%$ ( -0.7 to 9.6). The ETP decreased by $3.9 \%$, whereas the APCsr increased by $37.0 \%$ immediately after caesarean section. The changes in total protein S, prothrombin, thrombin generation and APC resistance showed a trend to be more pronounced in the subgroups with higher blood loss.

Discussion: Moderate blood loss during caesarean section hardly reduces thrombin generation but aggravates pregnancy-induced APC resistance and combined deficiency of TFPI and protein S, which can account for the increased thrombosis risk in early puerperium.
\end{abstract}

\section{Introduction}

In pregnancy the coagulation system undergoes physiological changes towards a hypercoagulant state, thereby preventing severe haemorrhage during delivery. Notwithstanding, postpartal haemorrhage ( $\mathrm{PPH})$ is still the leading cause for maternal death in developing countries [1]. Optimisation of the bleeding management allows to reduce maternal mortality due to $\mathrm{PPH}$ but on the other hand can aggravate the pre-existing hypercoagulability, thereby increasing the risk of another important pregnancy-related complication- venous thromboembolism (VTE) [1]. The risk on VTE is elevated 4 and 20 times during pregnancy and in puerperium respectively, as compared to agematched non-pregnant women [2]. The incidence of VTE is estimated to be highest during the first week after delivery, gradually decreasing thereafter and persisting over the 12th week postpartum [3]. Various genetic and acquired factors, such as thrombophilia, caesarean section, infection and severe blood loss can modulate the risk of pregnancyrelated VTE [1].

Pregnancy-induced changes in coagulation factors and anticoagulant proteins are thought to greatly contribute to the increased risk of VTE. Most coagulation factors are elevated during pregnancy [4], whereas anticoagulant proteins decrease progressively [4,5]. Additionally, fibrinolytic activity diminishes and the levels of thrombin activable fibrinolysis inhibitors increase during pregnancy [6,7]. These alterations may amplify or counteract each other, therefore the impact of particular changes on haemostasis is difficult to assess. Some evidence

\footnotetext{
* Corresponding author at: University Clinic for Gynaecology and Obstetrics, RWTH Aachen, Pauwelsstrasse 30, 52074 Aachen, Germany.

E-mail address: stchaikovski@ukaachen.de (S.N. Tchaikovski).
} 
suggests an importance of activated protein C (APC) and the protein S/ tissue factor pathway inhibitor (TFPI)-system in the pathogenesis of pregnancy-induced thrombosis [8]. Decreased sensitivity to APC, also known as APC resistance has been shown to be dose-dependently associated with the risk of VTE in different populations [9]. Several global coagulation tests were proposed to evaluate the net effect of single changes at different levels of the coagulation cascade and to assess APC resistance. Among others, calibrated automated thrombography-based assays, measuring the endogenous thrombin potential of plasma, were validated in various prothrombotic and haemophilic phenotypes. APC resistance test, based on the quantification of the effect of APC on the endogenous thrombin potential of plasma was shown to be particularly sensitive to coagulation changes during hormonal therapies and pregnancy [8].

Remarkably, PPH also increases the risk of VTE in puerperium, [1] despite a consecutive loss of coagulation factors. Blood loss over $1000 \mathrm{ml}$ increases the thrombosis risk 4-fold after vaginal delivery and even 12fold after caesarean section [10]. Blood transfusion, infusion and substitution therapies can additionally influence haemostasis. Therefore, exact knowledge on the changes occurring during and after bleeding and fluid administration is required for the optimal management of $\mathrm{PPH}$. However, the current guidelines are based on studies performed in nonpregnant patient populations, without considering the specificity of the coagulation changes during pregnancy. We hypothesised that PPH may increase the thrombosis risk by further aggravation of the pre-existing during pregnancy hypercoagulability. As the levels of natural inhibitors of coagulation are already decreased antepartum, blood loss can possibly affect the anticoagulant pathways to a greater extent as compared to the procoagulant mechanisms.

In the current prospective study, we investigated coagulation changes after caesarean section and their association with blood loss. The endogenous thrombin potential of plasma was chosen to assess the net effect of blood loss on coagulation. As the capacity of plasma to build the key enzyme of the coagulation cascade - thrombin - is largely determined by prothrombin [11], we also measured prothrombin levels. In order to evaluate changes in the anticoagulant pathways, we assessed APC resistance with a thrombin generation-based test. Protein S and TFPI are the major determinants of this assay [12] and were suggested to play a pivotal role in the development of APC resistance during pregnancy [8]. To confirm our hypothesis that peripartal blood loss can aggravate simultaneous deficiency of these proteins, we also evaluated changes in the protein S and TFPI levels.

\section{Materials \& methods}

\subsection{Collection of plasma samples}

Sample size was based on the number of subjects required to detect significant changes in the APC sensitivity ratio (APCsr) after blood loss during caesarean section. Assuming the standard deviation of the APCsr in pregnant women is 1.37 [8], we calculated that 40 women were needed to find a difference in the APCsr of 0.8 ( $\beta=0.95$ and $\alpha=0.05$ ).

We recruited prospectively 50 women who underwent elective caesarean section at term at the University Clinic of Magdeburg, Germany, between August 2014 and May 2015. Exclusion criteria were a personal or family history of VTE and coagulation disorders or medication that might interfere with blood coagulation. During hospital stay all participants obtained a prophylactic therapy with low molecular weight (LMWH), starting $6 \mathrm{~h}$ after caesarean section according to the national standards. Five blood samples were drawn: before, immediately, $6 \mathrm{~h}, 24 \mathrm{~h}$ and five days after the caesarean section. The later two samples were taken about $12 \mathrm{~h}$ after LMWH injection. All blood samples were proceeded to plasma as described before [13], snap frozen and stored at $-80{ }^{\circ} \mathrm{C}$ until analysis. The study was approved by the Medical Ethical Committee of the University of Magdeburg, Germany and registered with DRKS under DRKS00019879. All volunteers gave written informed consent. Pooled normal plasma was prepared by pooling plasma of 28 men and 17 women (mean age 33.6 years) and pooled pregnant plasma was prepared by pooling plasma of 23 healthy pregnant women (mean age 33.3 years) as previously described [14].

\subsection{Assessment of blood loss}

Assessment of blood loss during caesarean section was challenged by the presence of the amniotic fluid, therefore three different methods were used for this purpose. First, the surgeon estimated the blood loss visually. Additionally, the blood loss was objectively assessed by weighing the abdominal bandages and swabs used during the surgery under subtraction of the weight of dry materials. The amount of blood in the bandages, swabs and in the suction device bottles was corrected for the dilution with amniotic fluid. The dilution factor was calculated using the haemoglobin levels in blood (before caesarean section) and in the suction device bottles. Finally, blood loss was calculated using the "onecompartmental biometric method" (OCBM) described as V $=[0.0115 \times$ body weight $(\mathrm{kg}) \times \ln$ (preoperative $\mathrm{Hb} /$ postoperative $\mathrm{Hb})]+[0.1905$ $\times$ height $^{3}(\mathrm{~m}) \times \ln$ (preoperative Hb/postoperative Hb)] +0.3158 [15].

As fluid redistribution between the interstitium and plasma occurs gradually and is reflected by decreasing haemoglobin levels that reach a steady state approximately two days after acute bleeding [16], we calculated blood loss using the haemoglobin values determined $24 \mathrm{~h}$ after caesarean section. Blood loss calculated using the OCBM was used for statistical analysis. The pre-operative blood volume was calculated as follows: $\mathrm{V}=0.75 \times\{$ [maternal height (inches) $\times 50]+[$ maternal weight (pounds) $\times 25]\}[17]$.

\subsection{Materials and laboratory methods}

Prothrombin concentrations were determined in a chromogenic assay after complete activation of plasma prothrombin with Ecarin (Kordia Life Sciences, Leiden, the Netherlands) and subsequent measurement with the chromogenic thrombin substrate $D$-phenylalanyl-Lpipecolyl-L-arginine-p-nitroanilide (S2238, Chromogenix, Milano, Italy) [18]. Protein $\mathrm{S}_{\text {total }}$ and TFPI $\mathrm{fl}_{\mathrm{fl}}$ were determined using ELISA, as described elsewhere [19]. Prothrombin, protein $S_{\text {total }}$ and TFPI $I_{f l}$ levels were expressed in $\mathrm{U} / \mathrm{ml}$, where $1 \mathrm{U}$ is the amount present in $1 \mathrm{ml}$ of pooled normal plasma.

Thrombin generation was performed as previously described [20]. Briefly, the ETP was measured by calibrated automated thrombography (Stago) in reaction mixtures $(125 \mu \mathrm{l})$ containing $80 \mu \mathrm{l}$ plasma, $10.2 \mathrm{pM}$ tissue factor (Dade Innovin ${ }^{\circledR}$, Behring, Germany), $16 \mathrm{mM}$ added $\mathrm{CaCl}_{2}$, $30 \mu \mathrm{M}$ phospholipids, $0.32 \mathrm{mM}$ fluorogenic substrate Z-Gly-Gly-ArgAMC (Bachem, Bubendorf, Switzerland) in the absence (ETP-APC) and in the presence of $15 \mathrm{nM}$ APC (ETP + APC). 1,2-dioleoyl-sn-glycero-3-phosphoserine (DOPS), 1,2-dioleoyl-sn-glycero-3-phosphoethanolamine (DOPE), 1,2-dioleoyl-sn-glycero-3-phosphatidylcholine (DOPC), were from Avanti Polar Lipids, Alabaster, AL, USA. DOPS/DOPE/DOPC, 20/ 20/60, M/M/M vesicles were prepared as described before [20]. APC (Xigris $($ ) was obtained from Eli Lilly. The lag time, peak height, ETP, time to peak and time to start tail were calculated from thrombin generation curves by the software provided by Thrombinoscope B.V. (Maastricht, The Netherlands). The concentration of APC was chosen to inhibit approximately $85 \%$ of the ETP-APC in the pooled pregnant plasma. The ETP-APC and the ETP + APC were normalised for day-to-day variations and the APC sensitivity ratio (APCsr) was calculated as previously described, using pooled pregnant plasma as a reference [14]. Because of the prophylactic therapy with LMWH only the first three samples were used for the thrombin generation-based assays.

All laboratory tests were performed in duplicate.

\subsection{Statistical analysis}

The statistical analysis was performed with IBM SPSS Statistics 25. 
The Kolmogorov-Smirnov test was used to test for normal distribution and all data was visually assessed for linearity using scatter charts. Normally distributed data were expressed as mean with $95 \%$ confidence interval $(95 \% \mathrm{CI})$ and analysed with parametric tests (paired $t$-test). Not normally distributed parameters were expressed as median and range and analysed with non-parametric tests (Wilcoxon test). Correlations were evaluated by Pearson coefficient ( $r$ ) for normally linearly distributed parameters and Spearman coefficient $\left(r_{s}\right)$ for non-normally distributed values. $P<0.05$ was considered statistically significant. Eight blood samples after 5 days were missing due to an earlier discharge from the hospital and therefore pairwise excluded from the analysis.

\section{Results}

\subsection{Population baseline characteristics}

Table 1 summarises the baseline characteristics of the participants of the study. Fifty women meeting the inclusion and exclusion criteria were recruited to participate in the study. The study population was homogenous with respect to age and BMI, with an average of 30.7 years old and $23.3 \mathrm{~kg} / \mathrm{m}^{2}$, respectively. The indications for caesarean section were: one or more previous caesarean section 27 (54\%) or other previous uterus surgery $2(4 \%)$, breech presentation $12(24 \%)$, large for gestational age fetus and possible cephalopelvic disproportion $4(8 \%)$, twin pregnancy with non-cephalic presentation of the first fetus 2 (4\%), other medical conditions such as spondylolisthesis, previous multiple surgeries in the genital area and the patients request $3(6 \%)$. Most women had at least one pregnancy before, with a median of two previous pregnancies. The caesarean section was performed at term and the average fetal weight at birth was $3480 \mathrm{~g}$. None of the participants developed a VTE during pregnancy or in puerperium.

\subsection{Estimation of blood loss}

The blood loss estimated visually by the surgeon was not normally distributed and had a median of $500 \mathrm{ml}$ with a range between $247 \mathrm{ml}$ and $900 \mathrm{ml}$ (Table 1). The OCBM and the objective assessment resulted in somewhat higher volumes with a mean of $506 \mathrm{ml}$ (95\%CI: 456 to 557) and $611 \mathrm{ml}$ (95\%CI: 533 to 689), respectively (Table 1). The objectively evaluated blood loss correlated with visual assessment $r_{S}=0.41, p<$ 0.005 and with the values calculated via the OCBM $\mathrm{r}_{\mathrm{S}}=0.53, p<0.001$ and was significantly higher than the visual estimation, $p<0.014$. The mean pre-operative blood volume was calculated to be $6081 \mathrm{ml}$ (Table 1), meaning that the blood loss (OCBM) was $8.4 \%$ of the initial blood volume (95\%CI: 7.6 to 9.3). The perioperative fluid replacement was performed with a median of $1500 \mathrm{ml}$ crystalloid solutions (range 1000 to $2500 \mathrm{ml}$ ). No blood transfusion or colloid administration was

Table 1

Baseline characteristics.

\begin{tabular}{ll}
\hline Population baseline characteristic $(n=50)$ & Mean (95\% CI-Interval) \\
\hline Age, years & $30.7(29,5$ to 31,9$)$ \\
BMI, $\mathrm{kg} / \mathrm{m}^{2}$ & $23.3(22.5$ to 24.1$)$ \\
Previous pregnancies & $1(0-8)^{*}$ \\
Previous deliveries & $1(0-3)^{*}$ \\
Gestational age, weeks & $38,5(38,3$ to 38,7$)$ \\
Weight at birth, $g$ & $3480(3239$ to 3521$)$ \\
Calculated pre-operative blood volume, $\mathrm{ml}$ & $6081(5870$ to 6292$)$ \\
Estimated blood loss, ml & $500(247-900)^{*}$ \\
Blood loss calculated with OCBM, ml & $506(456$ to 557$)$ \\
Objectively assessed blood loss, ml & $611(533$ to 689$)$ \\
\hline
\end{tabular}

The data are presented in mean with $95 \% \mathrm{CI}$ in parenthesis, except for parameters that were not normally distributed $(*)$, where the values are provided as a median with range in parenthesis. BMI: body mass index, OCBM: 1-compartmental biometric method. carried out.

The haemoglobin levels decreased from the initial level of $7.5 \mathrm{mmol} /$ 1 (95\%CI: 7.4 to 7.7 ) by $6.9 \%$ (range $-28.8-56.9$ ), $6.9 \%$ (range -37.5-67.2), 8.8\% (range -28.2-7.5), 10.8\% (range -35.8-8.2) immediately, $6 \mathrm{~h}, 24 \mathrm{~h}$ and five days after caesarean section (Table 2). The haemoglobin changes did not correlate with the visually estimated blood loss. In contrast, the objectively evaluated blood loss showed a good correlation with the haemoglobin decrease, $\mathrm{r}_{\mathrm{S}}=0.55, p<0,001$. As the OCBM uses haemoglobin values for the calculation, an excellent correlation was observed between blood loss calculated via OCBM and the haemoglobin changes (data not shown).

\subsection{Prothrombin}

Mean prothrombin levels at baseline were $1.10 \mathrm{U} / \mathrm{ml}$ (95\%CI: 1.03 to 1.16) (Table 2). Prothrombin gradually decreased immediately and $6 \mathrm{~h}$ after surgery $(p<0.0001)$ and started increasing after 24 h. Five days after caesarean section the prothrombin levels exceeded the baseline, reaching $1.14 \mathrm{U} / \mathrm{ml}$ (range: $0.62-2.36$ ).

\subsection{Protein $S_{\text {total }}$}

The initial levels of protein $S_{\text {total }}$ showed a mean of $0.63 \mathrm{U} / \mathrm{ml}(95 \%$ CI: 0.60 to 0.67 ) (Table 2). The concentrations of protein $S_{\text {total }}$ decreased by $14.8 \%$ (95\%CI: -18.6 to -11.0 ), $\mathrm{p}<0.0001$ from the baseline immediately after caesarean section and remained stable $6 \mathrm{~h}$ after surgery (Table 2). Protein $S_{\text {total }}$ started to normalise after $24 \mathrm{~h}$ and reached $0.93 \mathrm{U} / \mathrm{ml}$ (95\%CI: 0.87 to 0.98 ) already five days after caesarean section.

\subsection{Tissue factor pathway inhibitor}

The baseline concentrations of $\mathrm{TFPI}_{\mathrm{fl}}$ were $0.47 \mathrm{U} / \mathrm{ml}$ (95\%CI: 0.41 to 0.53 ), hardly changed after caesarean section and slowly increased after five days by $11.5 \%$ (range: $-53.2-409$ ) (Table 2).

\subsection{Thrombin generation without APC}

Thrombin generation without APC showed an acceleration of the initiation phase of thrombin generation (lag time) by $11.8 \%$ (range: $-31.6-0.0$ ) and the time to peak by $8.4 \%$ (range: $-19.4-0.0$ ) immediately after the caesarean section $(p<0.001)$ and did not change significantly thereafter (data not shown) (Table 3). After the caesarean section the peak of thrombin and the ETP decreased by $5.5 \%$ (95\% CI:

Table 2

Changes in haemoglobin and coagulation parameters.

\begin{tabular}{|c|c|c|c|c|c|}
\hline & \multirow{2}{*}{$\begin{array}{l}\text { Baseline } \\
\text { level }\end{array}$} & \multicolumn{4}{|c|}{ Change after surgery } \\
\hline & & Immediately & $6 \mathrm{~h}$ & $24 \mathrm{~h}$ & 5 days \\
\hline $\mathrm{Hb}$ & $\begin{array}{l}7.5 \text { (7.4 to } \\
7.7)\end{array}$ & $\begin{array}{l}-6.9 \%(-28.8 \\
\text { to } 56.9)^{*}\end{array}$ & $\begin{array}{l}-6.9 \% \\
(-37.5 \text { to } \\
67.2)^{*}\end{array}$ & $\begin{array}{l}-8.8 \% \\
(-28.2 \text { to } \\
7.5)^{*}\end{array}$ & $\begin{array}{l}-10.8 \% \\
(-35.8 \text { to } \\
8.2)^{*}\end{array}$ \\
\hline PS & $\begin{array}{l}0.63(0.60 \\
\text { to } 0.67)\end{array}$ & $\begin{array}{l}-14.8 \% \\
(-18.6 \text { to } \\
-11.0)\end{array}$ & $\begin{array}{l}-13.4 \% \\
(-18.2 \text { to } \\
-8.6)\end{array}$ & $\begin{array}{l}-9.3 \% \\
(-13.9 \text { to } \\
-4.7)\end{array}$ & $\begin{array}{l}48.0 \% \\
(37.0 \text { to } \\
59.1)\end{array}$ \\
\hline $\operatorname{TFPI}_{\mathrm{fl}}$ & $\begin{array}{l}0.47(0.41 \\
\text { to } 0.53)\end{array}$ & $\begin{array}{l}1.1 \%(-100 \text { to } \\
55.3)^{*}\end{array}$ & $\begin{array}{l}-4.1 \% \\
(-31.5 \text { to } \\
38.1)^{*}\end{array}$ & $\begin{array}{l}6.3 \% \\
(-49.8 \text { to } \\
193)^{*}\end{array}$ & $\begin{array}{l}11.5 \% \\
(-53.2 \text { to } \\
409)^{*}\end{array}$ \\
\hline PT & $\begin{array}{l}1.10(1.03 \\
\text { to } 1.16)\end{array}$ & $\begin{array}{l}-10.4 \% \\
(-14.1 \text { to } \\
-6.8)\end{array}$ & $\begin{array}{l}-12.5 \% \\
(-16.9 \text { to } \\
-8.1)\end{array}$ & $\begin{array}{l}-9.3 \% \\
(-37.3 \text { to } \\
35.4)\end{array}$ & $\begin{array}{l}4.4 \%(-0.7 \\
\text { to } 9.6)\end{array}$ \\
\hline
\end{tabular}

Haemoglobin $(\mathrm{Hb})$ is expressed in $\mathrm{mmol} / \mathrm{l}$, total protein $\mathrm{S}$ (PS), tissue factor pathway inhibitor full length (TFPI $\mathrm{fl}_{\mathrm{fl}}$ ) and prothrombin (PT) are expressed in units considering that normal pooled plasma contains $1 \mathrm{U} / \mathrm{ml}$. The data are presented in mean with $95 \% \mathrm{CI}$ in parenthesis, except for parameters that were not normally distributed (*), where the values are provided as a median with range in parenthesis. 
Table 3

Thrombin generation parameters.

\begin{tabular}{|c|c|c|c|}
\hline & \multirow[t]{2}{*}{ Baseline } & \multicolumn{2}{|c|}{ Changes after caesarean section } \\
\hline & & Immediately & $6 \mathrm{~h}$ \\
\hline Lag no APC & $1.8(1.5-2.4)^{*}$ & $\begin{array}{l}-11.8 \% \\
(-31.6-0.0)^{*}\end{array}$ & $-9.7 \%(-28.4-0.0)^{*}$ \\
\hline ETP no APC & $996(637-1398) *$ & $\begin{array}{l}-3.9 \%(-5.7 \text { to } \\
-2.0)\end{array}$ & $\begin{array}{l}-4.7 \%(-7.1 \text { to } \\
-2.4)\end{array}$ \\
\hline Peak no APC & 373 (359 to 387 ) & $\begin{array}{l}-5.5 \%(-7.1 \text { to } \\
-3.8)\end{array}$ & $\begin{array}{l}-6.2 \%(-8.3 \text { to } \\
-4.1)\end{array}$ \\
\hline $\begin{array}{l}\text { ttpeak no } \\
\text { APC }\end{array}$ & $3.1(2.6-3.8)^{*}$ & $\begin{array}{l}-8.4 \% \\
(-19.4-0.0)^{*}\end{array}$ & $-8.5 \%(-18.0-0.0)^{*}$ \\
\hline $\begin{array}{l}\text { Start tail no } \\
\text { APC }\end{array}$ & $11.9(9.4-15.9)^{*}$ & $\begin{array}{l}0.0 \%(-15.0 \text { to } \\
17.0)^{*}\end{array}$ & $0.0(-9.0 \text { to } 22.0)^{*}$ \\
\hline $\mathrm{Lag}+\mathrm{APC}$ & $3.0(1.4-3.9)^{*}$ & $\begin{array}{l}0.0 \% \\
(-33.3-153.6)^{*}\end{array}$ & $3.9 \%(-27.3-162.3)^{*}$ \\
\hline $\mathrm{ETP}_{+\mathrm{APC}}$ & $\begin{array}{l}169.2 \\
(17.6-690.4)^{*}\end{array}$ & $\begin{array}{l}24.7 \% \\
(-62.3-397.1)^{*}\end{array}$ & $\begin{array}{l}40.0 \% \\
(-69.5-852.9)^{*}\end{array}$ \\
\hline Peak + APC & $50.6(2.1-247.5)^{*}$ & $\begin{array}{l}15.7 \% \\
(-67.9-537.1)^{*}\end{array}$ & $\begin{array}{l}36.5 \% \\
(-79.5-1784.5)^{*}\end{array}$ \\
\hline ttpeak + APC & $5.3(3.7-7.5)^{*}$ & $0.0 \%(-21.2-27.9) *$ & $0.0 \%(-16.4-23.1)^{*}$ \\
\hline $\begin{array}{l}\text { Start tail } \\
\quad+\mathrm{APC}\end{array}$ & $16.7(12.6-30.5)^{*}$ & $\begin{array}{l}2.9 \%(-39.0 \text { to } \\
58.0)^{*}\end{array}$ & $\begin{array}{l}3.1 \%(-33.0 \text { to } \\
95.0)^{*}\end{array}$ \\
\hline APCsr & $1.3(0.1-6.0)^{*}$ & $\begin{array}{l}37.0 \\
(-50.9-366.8)^{*}\end{array}$ & $39.7(-60.4-851.8)^{*}$ \\
\hline
\end{tabular}

Lag time (Lag), time to peak (ttpeak) and start tail are expressed in minutes, peak height in nM thrombin and the endogenous thrombin potential (ETP) in $\mathrm{nM}$ thrombin.minutes. The data are presented in mean with $95 \% \mathrm{CI}$ in parenthesis, except for parameters that were not normally distributed (*), where the values are provided as a median with range in parenthesis. APCsr: the APC sensitivity ratio.

-7.1 to -3.8$)$ and 3.9\% (95\%CI: -5.7 to -2.0$)$, respectively $(p<0.001)$ (Table 3). The reduction was even more pronounced after $6 \mathrm{~h}:-6.2 \%$ (95\%CI: -8.3 to -4.1 ) and $-4.7 \%$ (95\%CI: -7.1 to -2.4$)$, respectively $(p<0.0001)$ (Table 3).

\subsection{Thrombin generation in the presence of APC}

The time parameters of thrombin generation in the presence of APC did not change after caesarean section. In contrast the ETP + APC increased by $24.7 \%(p=0.015)$ and $40.0 \%(\mathrm{p}<0.0001)$ immediately and $6 \mathrm{~h}$ after caesarean section, respectively (Table 3 ). Similar changes were observed in the peak height and the APCsr, reaching an increase of $36.5 \%$ and $39.7 \%$, respectively after $6 \mathrm{~h}, \mathrm{p}<0.001$ (Table 3).

\subsection{Blood loss and coagulation changes}

The blood loss calculated with OCBM demonstrated the best correlations with the studied coagulation parameters, therefore this method was assumed to be the most accurate to measure blood loss after caesarean section and the data for the visual and objective assessment are not shown in the further analysis.

Changes in prothrombin immediately after caesarean section correlated with blood loss calculated using the OCBM, $r=-0.38, p<0.01$. The correlation remained significant in the later samples, becoming somewhat weaker with time. Additionally, significant correlations were found between the postoperative changes in prothrombin and the haemoglobin levels after six, $24 \mathrm{~h}$ and five days (data not shown).

Changes in protein $S_{\text {total }}$ immediately after the surgery also correlated with blood loss, $\mathrm{r}_{\mathrm{S}}=-0.4, p=0.002$, however this correlation disappeared in the later plasma samples. The same applies for the correlation of the protein $S_{\text {total }}$ changes and the postoperative haemoglobin decrease (data not shown). Interestingly, the changes in prothrombin and protein $\mathrm{S}_{\text {total }}$ correlated immediately after surgery, $\mathrm{r}_{\mathrm{S}}=0.48, p<$ 0.001 , but not thereafter. The TFPI $I_{\mathrm{fl}}$ changes correlated neither with the blood loss nor with the changes in prothrombin or protein $\mathrm{S}_{\text {total }}$ (Fig. 1).

Additionally, the correlation analysis showed an association of the blood loss (OCBM) with changes in the ETP and peak height in the absence of APC after $6 \mathrm{~h}$ with $r=-0.298, p=0.036$ and $r=-0.40, p=$ 0.004 , respectively. The correlations between blood loss and thrombin generation parameters in the presence of APC did not reach the level of statistical significance (data not shown).

To demonstrate the trends in the haemostatic changes as a function of the blood loss, the study population was divided according to the quartiles of the blood loss calculated via OCBM. The blood loss ranged from 176 to $387 \mathrm{ml}$, from 396 to $599 \mathrm{ml}$ and from 615 to $1015 \mathrm{ml}$ for the lower, median and upper quartiles, respectively. In line with the correlation analysis, protein $S_{\text {total }}$ and prothrombin gradually decreased from the lower to the upper quartile (data not shown). Further, the ETP decreased slightly in a dose dependent manner with an increasing blood loss (Fig. 2), reaching a median of $-11 \%$ decrease six hours after caesarean section for the upper quartile of the blood loss. In contrast, APC resistance gradually rose with increasing blood loss, reaching a median of $67 \%$ ( $6 \mathrm{~h}$ after surgery) for the upper quartile.

\section{Discussion}

In the present study we investigated changes of the coagulation system after caesarean section. Quantification of the blood loss during caesarean section is challenging, but can reliably be done with the OCBM [15]. Visual assessment underestimates the blood loss and correlates poorly with objective methods and with the changes in haemoglobin or coagulation parameters.

Similar to other surgical procedures [21], early changes in the studied coagulation parameters after caesarean section could be explained by blood loss and perioperative fluid administration. However, the initial state of the coagulation system before caesarean section
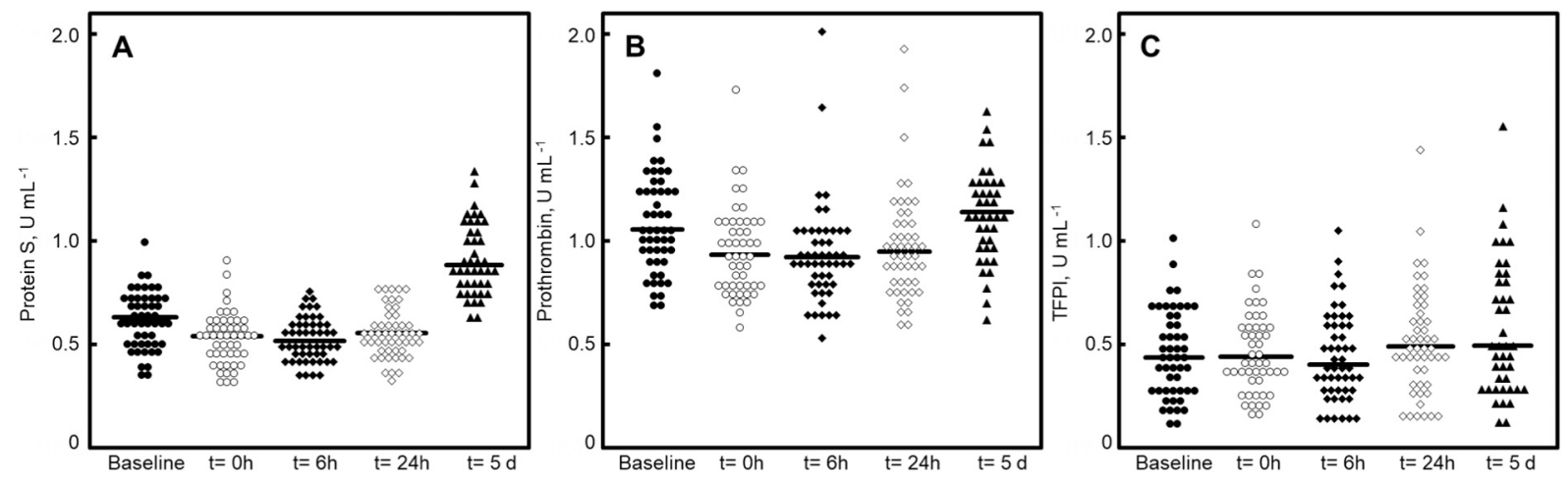

Fig. 1. Changes coagulation parameters after caesarean section.

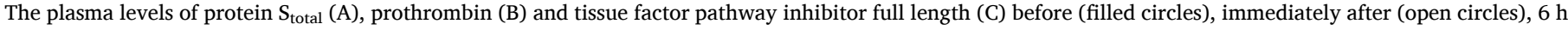
after (filled diamonds), $24 \mathrm{~h}$ after (open diamonds) and five days after caesarean section are presented. The solid lines represent the median of the group. 


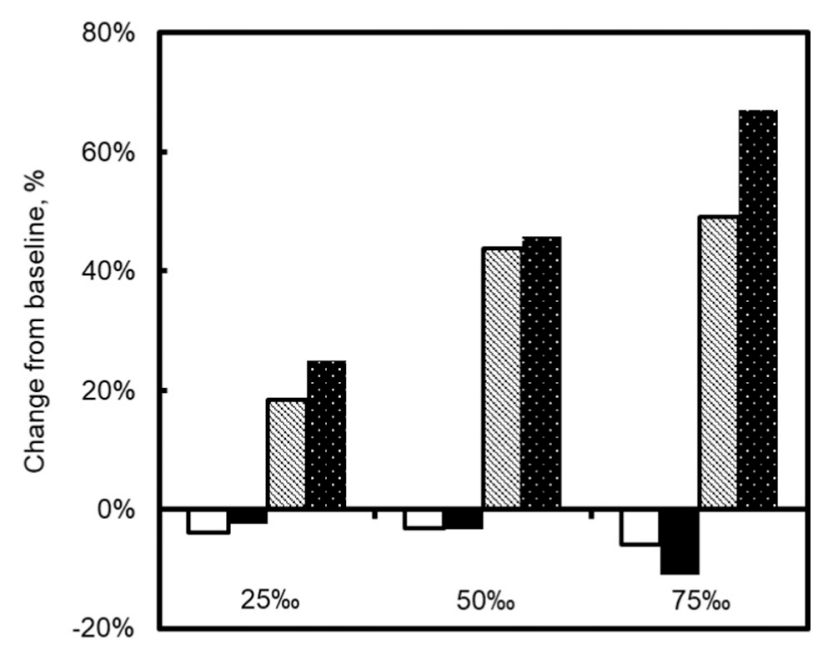

Fig. 2. Association of the ETP and APC resistance with the blood loss. The changes in the endogenous thrombin potential (ETP) immediately after (open bar) and $6 \mathrm{~h}$ after (filled bar) caesarean section as well as in the APCsr immediately after (dashed bar) and $6 \mathrm{~h}$ after (dotted bar) are depicted for the subgroups with the lower (25\%), the median (50\%) and the upper $(75 \%$ ) quartiles of the blood loss.

differs from that outside pregnancy. The haemostasis balance during pregnancy is already shifted towards a procoagulant state due to an elevation of coagulation factors and decrease of anticoagulant proteins $[4,5]$. Under these conditions, physiological peripartal blood loss leads to a normalisation or clinically not relevant decrease of coagulation factors. Only severe haemorrhage can cause a consumption coagulopathy, with prothrombin decrease likely to be one of the most important factors, reducing the capacity to generate the key enzyme of the coagulation cascade-thrombin [14,22]. Confirming previous data $[4,5]$, participants of our study had low protein $S$ and TFPI and high prothrombin levels before caesarean section. Blood loss and plasma dilution during surgery reduced levels of prothrombin and protein $S_{\text {total }}$. These changes correlated with each other and were determined by the blood loss. In contrast, $\mathrm{TFPI}_{\mathrm{fl}}$ demonstrated large inter-individual variation and did not change immediately after caesarean section, suggesting an influence of other regulating factors. For instance, a release of TFPI by endothelial cells after exposure to tissue factor during surgery [23] could be one of the possible mechanisms counteracting the influence of the blood loss.

Consistent with reports on coagulation changes after other major surgeries [21], we could detect a marginal decrease in the ETP after caesarean section that was more pronounced in the subgroup with higher blood loss. Thrombin generation was accelerated immediately after caesarean section (Table 3 ) without significant correlation with the blood loss, which could possibly be explained by the tissue damage and release of procoagulant substances. After delivery the probability of haemorrhagic complications declines rapidly, whereas the risk of VTE increases, reaching the peak during the first postpartum week [3]. Interestingly, the thrombosis risk is higher after PPH [1], despite the loss of coagulation factors and a decrease in the ETP. Consequently, the changes in thrombin generation cannot explain the elevated thrombosis risk in puerperium. APC resistance correlates with the risk of VTE in different populations with and without genetic thrombophilia [9]. In line with previous reports [24], pregnant women in our study were more resistant to APC as compared to the normal plasma (data not shown), reflecting a higher risk of VTE during pregnancy. Moreover, APC resistance increased immediately after caesarean section and correlated with the blood loss (Fig. 2). As protein S and TFPI are the major determinants of the APCsr, a decrease of protein $\mathrm{S}_{\text {total }}$ and the persisting low TFPI $\mathrm{fl}_{\mathrm{fl}}$ levels after caesarean section could account for postpartum APC resistance. The plasma levels of protein $S$ and $\mathrm{TFPI}_{\mathrm{fl}}$ in our study population after the surgery were about half of those in normal plasma. Such low protein $S$ levels were comparable to the cut-off levels for protein $S$ deficiency $(2.5 \%)$ in women using oral contraceptives in the LETS study and were associated with a 2.4-fold increase of the VTE risk [25]. The same study provided evidence that low TFPI levels are also related to an increased risk of VTE [26]. Altogether this suggests that simultaneously reduced levels of anticoagulant proteins, occurring due to the pregnancy-induced hormonal changes and postpartum blood loss, can account for the increased thrombosis risk in the early puerperium, particularly after excessive bleeding. This hypothesis is further supported by the observation of James et al., demonstrating an antithrombin decrease of $30 \%$ after delivery [27]. Natural anticoagulants that remain unchanged or increase in pregnancy, e.g. protein $\mathrm{C}$ and thrombomodulin are most likely to normalise or slightly diminish after moderate blood loss and, therefore, are probably less relevant for the pathogenesis of VTE after peripartal haemorrhage. Additionally, lower mobility due to acute anaemia may further increase the risk of postpartum VTE.

Interestingly, the normalisation of the studied proteins after caesarean section followed various patterns, suggesting involvement of different regulatory mechanisms. TFPI $\mathrm{fl}_{\mathrm{fl}}$ levels rose slowly and reached $0.58 \mathrm{U} / \mathrm{ml}$ on the fifth day after the surgery. Since TFPI can be downregulated by oestrogens [28], their increased levels during pregnancy and rapid decrease after delivery [29] could explain the observed changes of TFPI $\mathrm{fl}_{\mathrm{fl}}$. Additionally, a partial depletion of free TFPI after repetitive injections of LMWH was demonstrated previously and could slow down normalisation of TFPI $\mathrm{f}_{\mathrm{fl}}$ in our study population [30]. However, the effect of subcutaneous application of a prophylactic dose of LMWH on the TFPI $\mathrm{fl}_{\mathrm{fl}}$ levels is much less pronounced as that of unfractionated heparin [30]. The prothrombin changes correlated with the blood loss at all studied time points, implying the major influence of this factor on the prothrombin levels. Remarkably, prothrombin did not only normalise, but even slightly exceeded the elevated preoperative values. This excessive increase can result from an influence of the residually elevated steroid hormones [31] in early puerperium, combined with the acute-phase response [32]. In line with previous reports [33], we observed a rapid postoperative increase of protein $S$, with a steeper incline as compared to that of prothrombin or TFPI $\mathrm{fl}_{\mathrm{fl}}$, so that it nearly doubled within five days. The correlation between the changes in protein $\mathrm{S}_{\text {total }}$ and blood loss as well as prothrombin disappeared already $6 \mathrm{~h}$ after surgery, suggesting involvement of other regulation mechanisms. As protein $S$ is an estrogen-dependent protein [34], normalisation of steroid hormones is undoubtedly one of these mechanisms. However, hormonal changes are possibly responsible for slower changes, like those observed in the TFPI $\mathrm{fl}_{\mathrm{fl}}$ levels. Yet, the time courses of hormoneinduced changes in the synthesis and release of TFPI and protein $S$ by endothelium can differ from that of prothrombin and protein $S$ in the liver cells. Additionally, a transient increase of protein $S$ after a major abdominal surgery was described before in non-pregnant women [35], suggesting its upregulation in the acute phase, which can additionally contribute to the rapid postoperative normalisation of protein $S_{\text {total }}$ in our study.

Surprisingly limited data are available on the effect of peripartal blood loss on the coagulation system besides the clinical routine tests. We present here the results of a prospective study in a well characterised homogenous collective, where changes in thrombin generation, APC resistance as well as in prothrombin, protein $S_{\text {total }}$ and $\mathrm{TFPI}_{\mathrm{fl}}$ were investigated after primary caesarean section with respect to the peripartal blood loss. Our study has a few limitations, among others is a relatively narrow range of blood losses during surgery due to the defined inclusion criteria and a low risk for PPH during elective caesarean section. Only five women had a blood loss exceeding $1000 \mathrm{ml}$ and thereby fulfil the criteria of PPH, which allowed us to detect only trends in the coagulation changes with increasing blood loss. Additionally, the thrombin generation-based assays could only be performed on the samples obtained before the first administration of LMWH. However, to 
our knowledge this is the first study addressing the coagulation changes after peripartal blood loss as a predisposing factor for VTE in puerperium.

In conclusion, we demonstrated considerably reduced levels of TFPI and protein $\mathrm{S}$ and increased APC resistance after caesarean section. The changes in protein S and APC resistance were more pronounced in the subgroup with higher blood loss. Simultaneously decreased levels of natural coagulation inhibitors after peripartal blood loss can be a plausible explanation for an increased risk of VTE, associated with PPH. The current recommendations for the management of PPH are based on the randomised trials in non-pregnant patients and the special features of the coagulation system during pregnancy are not given sufficient consideration. Based on our data, we suggest that there is a need for further research, investigating effects of infusion and substitution therapies for bleedings in pregnant women in order to optimise management of PPH. For instance, an excessive crystalloid administration during PPH can lead to further plasma dilution with subsequent lowering of the natural inhibitors, secondarily increasing the VTE risk and, therefore, should be avoided. Additionally, a prophylactic administration of LMWH after achieving haemostasis, should be carefully considered in early puerperium after severe postpartum bleeding to reduce the risk of postpartum VTE.

\section{Declaration of competing interest}

The authors declare that they have no known competing financial interests or personal relationships that could have appeared to influence the work reported in this paper.

\section{Acknowledgement}

We would like to acknowledge the team of the University Clinic of Magdeburg, Germany and Victoria Kuhnt for their support in the recruitment of the patients and collection of the blood samples.

This research did not receive any specific grant from funding agencies in the public, commercial, or not-for-profit sectors.

\section{Addendum}

W.A.: coagulation assays, statistical analysis, writing a draft of the manuscript. T.M.C.L.G.D.: assistance and supervision of the experimental work, revising the manuscript. C.S.D.: supervision of the clinical work, revising the manuscript. Z.A.: logistics, study preparation, revising the manuscript. T.V. interpretation of the data, statistical an alysis, revising the manuscript. S.E.: interpretation of the data from clinical point of view, revising the manuscript. T.M.H.: interpretation of the TFPI and thrombin generation data from a biochemical point of view, revising of the manuscript. T.S.N.: study design and concept, patient recruitment, thrombin generation assays, revising of the manuscript.

\section{References}

[1] A.H. James, M.G. Jamison, L.R. Brancazio, et al., Venous thromboembolism during pregnancy and the postpartum period: incidence, risk factors, and mortality, Am. J. Obstet. Gynecol. 194 (5) (2006) 1311-1315.

[2] A.H. James, Venous thromboembolism in pregnancy, Arterioscler. Thromb. Vasc. Biol. 29 (3) (2009) 326-331.

[3] N.K. Tepper, S.L. Boulet, M.K. Whiteman, et al., Postpartum venous thromboembolism: incidence and risk factors, Obstet. Gynecol. 123 (5) (2014) 987-996.

[4] P.B. Szecsi, M. Jorgensen, A. Klajnbard, et al., Haemostatic reference intervals in pregnancy, Thromb. Haemost. 103 (4) (2010) 718-727.

[5] O. Erez, R. Romero, E. Vaisbuch, et al., High tissue factor activity and low tissue factor pathway inhibitor concentrations in patients with preterm labor, J. Matern Fetal Neonatal Med. 23 (1) (2010) 23-33.

[6] M. Coolman, C.J. de Groot, E.A. Steegers, et al., Concentrations of plasminogen activators and their inhibitors in blood preconceptionally, during and after pregnancy, Eur. J. Obstet. Gynecol. Reprod. Biol. 128 (1-2) (2006) 22-28.
[7] H.A. Mousa, C. Downey, Z. Alfirevic, et al., Thrombin activatable fibrinolysis inhibitor and its fibrinolytic effect in normal pregnancy, Thromb. Haemost. 92 (5) (2004) 1025-1031.

[8] S.N. Tchaikovski, M.C. Thomassen, S.D. Costa, et al., Role of protein S and tissue factor pathway inhibitor in the development of activated protein $\mathrm{C}$ resistance early in pregnancy in women with a history of preeclampsia, Thromb. Haemost. 106 (5) (2011) 914-921.

[9] S.N. Tchaikovski, J. Rosing, Mechanisms of estrogen-induced venous thromboembolism, Thromb. Res. 126 (1) (2010) 5-11.

[10] A.F. Jacobsen, F.E. Skjeldestad, P.M. Sandset, Ante- and postnatal risk factors of venous thrombosis: a hospital-based case-control study, J. Thromb. Haemost. 6 (6) (2008) 905-912.

[11] S. Butenas, C. van't Veer, K.G. Mann, "Normal" thrombin generation, Blood. 94 (7) (1999) 2169-2178.

[12] M.C. de Visser, Vlieg A. van Hylckama, G. Tans, et al., Determinants of the APTTand ETP-based APC sensitivity tests, J. Thromb. Haemost. 3 (7) (2005) 1488-1494.

[13] L.F. Maurissen, E. Castoldi, P. Simioni, et al., Thrombin generation-based assays to measure the activity of the TFPI-protein $\mathrm{S}$ pathway in plasma from normal and protein S-deficient individuals, J. Thromb. Haemost. 8 (4) (2010) 750-758.

[14] S.N. Tchaikovski, H.A. van Vliet, M.C. Thomassen, et al., Effect of oral contraceptives on thrombin generation measured via calibrated automated thrombography, Thromb. Haemost. 98 (6) (2007) 1350-1356.

[15] N. Milosevic, J. Popovic, Z. Grujic, et al., One-compartmental biometric blood loss calculation after cesarean section, Eur. J. Drug Metab. Pharmacokinet. 36 (3) (2011) 183-188.

[16] N.S. Nagra, D. van Popta, S. Whiteside, et al., An analysis of postoperative hemoglobin levels in patients with a fractured neck of femur, Acta Orthop. Traumatol. Turc. 50 (5) (2016) 507-513.

[17] I. Stafford, G.A. Dildy, S.L. Clark, et al., Visually estimated and calculated blood loss in vaginal and cesarean delivery, Am. J. Obstet. Gynecol. 199 (5) (2008) 519. e511-519.e517.

[18] S.N. Tchaikovski, M.C. Thomassen, S.D. Costa, et al., Changes in haemostatic parameters during the menstrual cycle and subsequent use of drospirenonecontaining oral contraceptives, Thromb. Res. 134 (5) (2014) 1032-1037.

[19] E. Castoldi, J.M. Brugge, G.A. Nicolaes, et al., Impaired APC cofactor activity of factor $\mathrm{V}$ plays a major role in the APC resistance associated with the factor V Leiden (R506Q) and R2 (H1299R) mutations, Blood. 103 (11) (2004) 4173-4179.

[20] S.N. Tchaikovski, B.J. van Vlijmen, A.C. Cleuren, et al., Pregnancy-associated changes in the hemostatic system in wild-type and factor V Leiden mice, J. Thromb. Haemost. 7 (2) (2009) 312-318.

[21] L. Spiezia, F. Vasques, A. Behr, et al., Perioperative coagulation assessment of patients undergoing major elective orthopedic surgery, Intern. Emerg. Med. 11 (6) (2016) 793-801.

[22] A.W. Dielis, E. Castoldi, H.M. Spronk, et al., Coagulation factors and the protein C system as determinants of thrombin generation in a normal population, J. Thromb. Haemost. 6 (1) (2008) 125-131.

[23] R. Slusarz, M. Glowacka, M. Biercewicz, et al., Tissue factor and tissue factor pathway inhibitor in the wound-healing process after neurosurgery, Biol. Res, Nurs. 18 (2) (2016) 207-212.

[24] M.C. Walker, P.R. Garner, E.J. Keely, et al., Changes in activated protein C resistance during normal pregnancy, Am. J. Obstet. Gynecol. 177 (1) (1997) $162-169$.

[25] G. Liberti, R.M. Bertina, F.R. Rosendaal, Hormonal state rather than age influences cut-off values of protein S: reevaluation of the thrombotic risk associated with protein S deficiency, Thromb. Haemost. 82 (3) (1999) 1093-1096.

[26] A. Dahm, Vlieg A. Van Hylckama, B. Bendz, et al., Low levels of tissue factor pathway inhibitor (TFPI) increase the risk of venous thrombosis, Blood. 101 (11) (2003) 4387-4392.

[27] A.H. James, E. Rhee, B. Thames, et al., Characterization of antithrombin levels in pregnancy, Thromb. Res. 134 (3) (2014) 648-651.

[28] A.E. Dahm, N. Iversen, B. Birkenes, et al., Estrogens, selective estrogen receptor modulators, and a selective estrogen receptor down-regulator inhibit endothelial production of tissue factor pathway inhibitor 1, BMC Cardiovasc. Disord. 6 (2006) 40.

[29] J.A. Kremer, R. Rolland, P.F. van der Heijden, et al., Return of gonadotropic function in postpartum women during bromocriptine treatment, Fertil. Steril. 51 (4) (1989) 622-627.

[30] B. Bendz, J.B. Hansen, Andersen TO, et al., Partial depletion of tissue factor pathway inhibitor during subcutaneous administration of unfractionated heparin, but not with two low molecular weight heparins, Br. J. Haematol. 107 (4) (1999) $756-762$.

[31] F.K. Beller, C. Ebert, Effects of oral contraceptives on blood coagulation. A review, Obstet. Gynecol. Surv. 40 (7) (1985) 425-436.

[32] S. Jain, V. Gautam, S. Naseem, Acute-phase proteins: as diagnostic tool, J. Pharm. Bioallied. Sci. 3 (1) (2011) 118-127.

[33] J. Malm, M. Laurell, B. Dahlback, Changes in the plasma levels of vitamin Kdependent proteins $\mathrm{C}$ and $\mathrm{S}$ and of C4b-binding protein during pregnancy and oral contraception, Br. J. Haematol. 68 (4) (1988) 437-443.

[34] A. Suzuki, N. Sanda, Y. Miyawaki, et al., Down-regulation of PROS1 gene expression by 17 beta-estradiol via estrogen receptor alpha (ERalpha)-Sp1 interaction recruiting receptor-interacting protein 140 and the corepressor-HDAC3 complex, J. Biol. Chem. 285 (18) (2010) 13444-13453.

[35] R. Warwick, R.A. Hutton, L. Goff, et al., Changes in protein C and free protein S during pregnancy and following hysterectomy, J. R. Soc. Med. 82 (10) (1989) $591-594$. 